\title{
PERSONAL COMPETENCES OF ABSOLVENTS AS PREREQUISITE OF SOCIAL INCLUSION
}

\author{
[OSOBNOSTNE KOMPETENCIE ABSOLVENTOV AKO \\ PREDPOKLAD SOCIALNEJ INKLUZIE]
}

\author{
Jana Duchovicova - Gabriela Petrova
}

\author{
doi: 10.18355/PG.2016.5.1.184-200
}

\begin{abstract}
The aim of the theoretical study is to analyze philosophical and social aspects that determine changes in the aims of education in the context of applying of the absolvents in the praxis and as the end result of social inclusion of the absolvents. Intention of the authors is also to raise public awareness to the trends of segregation of the education in the educational scope and emphasize the need of intensive care of cultivation of personal and social potential of students as primary requirement of their social inclusion and versatility. The emphasis is on the characteristics of the changes of education in the context of globalization of the society, understanding wisdom as premise to succes in life, aspects of education in confrontationof personal competences, philosophy of mediation in educational process as premise of succesful social inclusion and in the last part the focus on personal competences needed for applyinf on the labor market.
\end{abstract}

\section{Key words}

Personal competences of the absolvents, globalization, social consequences of globalization, wisdom, hidden knowledge, mediation in educational process

\begin{abstract}
Abstrakt
Ciel'om teoretickej štúdie je analyzovat' filozoficko-spoločenské aspekty determinujúce zmeny v ciel'och výchovy a vzdelávanie v kontexte uplatnenia absolventov $\mathrm{v}$ praxi a v konečnom dôsledku smerujúce k sociálnej inklúzii absolventov. Zámerom autoriek je tiež upriamit' pozornost' pedagogickej verejnosti na trendy oddel'ovania sa výchovy a vzdelávania $\mathrm{v}$ edukačnom rámci a zdôraznit' potrebu intenzívnejšie venovat' pozornost' kultivácii osobnostného a sociálneho potenciálu žiakov ako primárnej požiadavky ich sociálnej inklúzie a uplatnenia. Dôraz je kladený na charakteristiku premien vzdelávania v kontexte globalizácie spoločnosti, ponímanie múdrosti ako predpokladu životného úspechu, aspekty výchovy v konfrontácii základov personálnych kompetencií, filozofiu sprostredkovania $v$ edukačnom procese ako predpokladu úspešnej sociálnej inklúzie a v záverečnej časti sa sústredí na personálne kompetencie potrebné pre uplatnenie na trhu práce.
\end{abstract}




\section{Kl'účové slová}

Personálne kompetencie absolventa, globalizácia, sociálne dôsledky globalizácie, múdrost', skryté poznatky, sprostredkovanie v edukačnom proces.

\section{Úvod}

Uvažovanie edukátorov o vzdelávaní, jeho obsahovom napĺnaní v kontexte potrieb spoločnosti a potrieb trhu práce zastáva na oddelení vzdelávania od výchovy, na oddelení kognitivizačných snáh od snáh socializačných, emocionalizačných a personalizačných. Otázkou je prečo je nutné zamýšl’at' sa nad odizolovaním ciel'ov vzdelávania a ciel’ov vychovávania v druhom desat'ročí 21. storočia, ked' prvé vel'ké paradigmy edukácie výchovu a vzdelávanie dokázali neoddelitel'ne integrovat' a zabezpečit' tak rovnováhu funkcií a hodnôt vzdelania?

Filozofické ponímanie stavia aj poslednú paradigmu edukácie na hodnotových ideáloch a formovaní človeka, aby mohol byt' začlenený do aktuálneho sveta, ale vybavuje ho zároveň kompetenciami pre jeho ovládnutie. Prevzatím starostlivosti štátu (nie len u nás) sa poznávanie odosobňovalo a odosobňuje sa, zužuje sa na inštitucionálnou sférou, sprostredkované informovanie, ktoré je hodnotovo neutrálne, primárne zamerané na život a prácu v danej spoločnosti. Avšak v poslednom období sa táto homogenizujúca a integrujúca funkcia edukácie oslabuje. Ideál utvárania originálnej, individuálnej, sebastimulujúcej, autentickej, vnútorne integrovanej a socializovanej osobnosti je ohrozovaný stimulmi ovplyvňovania. (vol'ne podl'a Kosova, 2013). Rizikovým je, ak sa procesy utvárania a rozvíjania osobnosti človeka neriadia humánnymi princípmi, ale požiadavkami trhu. „Rizikovej“ edukácii, mechanizmami trhu ovplyvňovanej ciel'ovej orientácii edukácie najvýraznejšie prispievajú globalizačné procesy, ktoré našu spoločnost' ovládli najmä v posledných desat'ročiach.

Výchova a z nej vydelené vzdelávanie sa riadi spoločenskou objednávkou a nie nadčasovými hodnotami, čo má za následok formalizáciu vzt’ahov medzi vyučujúcimi a učiacimi sa a v najnovších globalizáciou ovplyvnených výchovných trendoch vzt’ah medzi aktérmi výchovy vôbec nie je nutný (dištančné vzdelávanie).

Odpoved' na otázku orientácie osobnostných kompetencií, hodnotovo postojovej, záujmovo - ašpiračnej, komunikačno-hodnotiacej, autoevaluačnej a autoregulačnej úrovne a spôsobilosti mladého človeka ukotvujeme vglobálnych súvislostiach výchovy, kognitivistickom pojednaní o múdrosti v sprostredkujúcej filozofii učenia a sociálnej inklúzie.

\section{Globalizačné kontexty ako determinanty premien edukácie}

Globalizačné procesy sa najintenzívnejšie rozvíjajú od sedemdesiatych rokov 20. storočia, čo má za následok výraznú premenu charakteru 
spoločnosti vo všetkých jej zretel'och. Globalizačné zmeny mali výraz nadnárodnosti a znižovania suverenity procesov spájaných s národným riadením. To čo bolo predtým národné, lokálne - ekonomika, politika, kultúra, ekológia, sociálne, pracovné a občianske otázky, konštatuje B. Kosova (2013: 138), sa zmenilo na procesy spravované nadnárodnými aktérmi, vzdelávanie nevynímajúc.

M. Petrusek (2003: 99) charakterizuje dané zámery ako úsilie urobit' svet usporiadanejším a jednoznačným, a to s využitím modernej vedy a všetkých legitímnych (príp. nelegitímnych) prostriedkov politiky. Globalizačné procesy zároven̆ vytvorili priestor pre utváranie sietí, mocenský a konkurenčný boj a svetový trh vytesňuje a nahrádza politické konanie. Vytvárajú sa „národné obce“, ktoré charakterizujú podl'a V. Mezricky (2003: 10) spontánne, neriadené procesy, ovplyvňujúce životný štýl (hudba, šport, ekológia), hnutia, profesijné a vedecké komunity a rôzne formy a štruktúry riadiace procesy naprieč kontinentmi (napr. finančné toky, banky, formy práce, produkcie, kooperácie, vyhodnocovania - ratingy , rankingy, formy zábavy, komunikácie a pod. (In Kosova, 2013: 138).

U. Beck (2007: 21) konštatuje, že ide o široké spektrum procesov vymykajúcich sa kontrole národných štátov, ktoré spontánne a nekoordinovane vedú $\mathrm{k}$ integráciám na vyššej úrovni.

Nad typickými črtami súčasnej doby sa zamýšl'a aj K. Lorenz (1990) a nazýva ich výstižne osem smrtel'ných hriechov, pretože majú zásadný vplyv na tendenčnost' vývinu spoločnosti a bezprostredný dopad na efekty výchovného pôsobenia v najširšom slova zmysle. K hriechom súčasnej doby zarad'uje uponáhl'anost', prel'udnenost' sídlisk vedúcu k nezáujmu a vzájomnej l'ahostajnosti, stratu zmyslu pre zodpovednost', nesúlad s tradíciami, zvyšujúcu sa poddajnost' voči doktrínam, devastáciu prostredia, genetický úpadok a nebezpečenstvo atómovej skazy.

Ku globálnym zmenám ovplyvňujúcim výchovu zarad'uje J. Pelikan (2011: 23) :

- nové modely existencie, ktoré zneist'ujú l'udí a opierajúc sa o I. Hoffmana poukazuje na uprednostňovanie konkurencie pred solidaritou, čo má priamy dopad na nerovnomerné rozvrstvenie spoločnosti.

- Zmeny politických a ekonomických pomerov, ktoré majú za následok existenčné problémy l'udí vyplývajúce zo zvyšujúcej sa nezamestnanosti l'udí .

- Myslenie a postoje mladých l’udí - vyplývajú z nevyhnutnosti zabezpečenia samého seba, čo sa odráža v hl'adaní zmyslu života.

Základnými znakmi globalizácie podl’a B. Kosovej (2013: 139) sú:

- Ambivalencia - ten istý jav môže mat' súčasne pozitívne i negatívne hodnotenie (nadnárodné spoločnosti sú aj nie sú impulzom pre rozvoj lokálnych ekonomík, masová kultúra je aj nie je demokratizáciou kultúry, uvol'nenie morálnych noriem je aj nie je oslobodením indivídua, globalizácia zlepšuje aj zhoršuje podmienky l'udí).

- Zmena chápania priestoru a času v živote l’udstva - celosvetový priestor je priestorom malým a l'ahko dostupným reálne aj virtuálne. Prostredníctvom technológií môže byt' virtuálne nastolená súčasnost' 
nesúčasných udalostí. Udalosti sa odohrávajú takmer súčasne i virtuálne vo všetkých svetových priestoroch, čo vyvoláva umelé ret'azce príčin a následkov - vzniká časovo kompaktný svet, v ktorom človek žije prostredníctvom technológií (internet, telefóny) s niekým, ale pritom na opačnej strane sveta, alebo na viacerých miestach za rok, či na cestách). Vd’aka informačno - komunikačným technológiám možno vidiet' akékol'vek miesto na svete, regionálna udalost' (predtým nepovšimnutá) sa stáva súčast'ou svetového diania, hit austrálskeho speváka okamžite počut' v slovenskom éteri, hospodársky problém jednej krajiny otrasie burzou na druhej strane zemegule.

Globalizácia štiepi l’udí na globalizovaných bohatých s nedostatkom času a bez t’ažkostí prekonávajúcich akékol'vek vzdialenosti a lokalizovaných chudobných, ktorí nevedia čo s časom, pripútaných $\mathrm{k}$ jednému priestoru.

Najvýraznejšími sociálnymi dôsledkami podl’a spomínanej autorky (140141) sú:

- Nerovnomernost' rozdelenia bohatstva.

- $\quad$ Rozklad prirodzených lokálnych i národných spoločenstiev.

- Bezohl'adnejšie prístupy k riadeniu.

- Nezodpovednost' nadnárodných zoskupení za lokálne ekologické dôsledky.

- Rast sociálneho napätia.

- Totálna ekonomizácia života spoločnosti

Uvádzaný vývin globalizačných dôsledkov smeroval k aktivitám Medzinárodného spoločenstva orientovaných na zabezpečenie udržatel'ného rozvoja a zvýšenie kvality života spojenej so subjektívnym vnímaním životnej spokojnosti. Postupne, v kontexte prekonávania dopadov globalizácie na spoločnost' sa rozvíja filozofia holizmu, ktorá programovo rieši otázniky budúcnosti z pohl'adu globálneho chápania sveta.

Zdrojom uvažovania o osobnostných kompetenciách človeka pripraveného pre sociálnu inklúziu a pracovný trh, či celoživotné vzdelávanie sú štyri vzájomne prepojené vzt’ahy, ktoré charakterizujú G. Pike a D. Selby (1994: 19).

1. Priestorový rozmer globality - chápanie sveta ako multidimenzionálneho komplexného systému, v ktorom systém predstavuje viac ako len súčet častí (široké ekonomické finančné informačno-komunikačné ekologické súvislosti) vyžadujúce si adekvátnu ekonomicko-finančnú, ekologicko-environmentálnu a informačno-komunikačnú gramotnost' mladého človeka - absolventa sekundárneho či terciárneho vzdelávania.

2. Časový rozmer globality - aktuálne činy človeka ovplyvňujú budúcnost'. Súčasné problémy sú výsledkami minulých činov.

Vol'ba možnej budúcnosti je determinovaná: vedomým rozhodovaním vychádzajúcim zo schopnosti človeka posúdit' príčinno - následné vzt'ahy, kauzalitu rozmanitých spoločenských, ekonomických, kultúrnych javov, tiež angažovanou účast'ou - vychádza z vnútornej, ale i vonkajšej 
motivácie riadenej vlastnými postojmi a hodnotami človeka, zmysluplným konaním - pričom zmysluplnost' je ovplyvnená subjektívne zdôvodneným rozmerom vlastného konania so schopnost'ou argumentácie pohnútok a osobných presvedčení opierajúcich sa o metakognitívne stratégie a logiku. Osobnostné kompetencie vzt'ahujúce sa k schopnosti vol'by vlastnej budúcnosti predstavujú kompetencie k učeniu, riešeniu problémov, strategickému mysleniu a plánovaniu, zameraniu na ciel', ale tiež kompetencie občianske, komunikačné, inter a intrapersonálne - prebratie zodpovednosti, sebareflexia, schopnost' správne a kriticky vyhodnocovat' sociálne sprostredkovanú spätnú väzbu - sebapoznanie, schopnost' adekvátne hodnotit' iných l'udí, ich osobnost' a prejavy, schopnost' riadit' seba samého, sebaistota, racionálna práca a i.

3. L'udský rozmer globality - je ponímaný v kontexte prepojenosti a neoddelitel'nosti človeka a globálne chápaného sveta. Zmena sveta závisí od vnútornej premeny človeka. Podmienkou riešenia je dosiahnutie lepšej vnútornej rovnováhy človeka so svetom. Vyžaduje si schopnost' úsudku, vyvodzovat' závery z analógie, abstrakciu, predvídavé myslenie, disciplínu, vedomie zodpovednosti za kvalitu a následky svojho správania.

4. Globálny rozmer problémov - globálne problémy majú systémovú povahu, teda nie je možné ich rozkúskovat' a riešit' izolovane. Dôležitá je syntéza a stály podiel všetkých jednotlivcov, čo si vyžaduje aplikáciu techník komunikácie, kooperácie, techník učenia a techník duševnej práce, samostatnost', zodpovednost' a schopnost' znášat' zát’až.

Problémy súčasnej doby (vol’ne podl'a Kosovej, 2013: 144), v holistickom ponímaní nie je možné riešit' izolovane. Riešenie vyžaduje všeobecnú zmenu spôsobu života a hl'adanie rovnováhy medzi sebapresadzovaním a príslušnost'ou $\mathrm{k}$ celku - systému.

Všeobecnú zmenu spôsobu života vel'kého počtu l'udí je možné dosiahnut' iba zmenou výchovy. Súčasná doba kladie na výchovu náročné požiadavky. Je potrebné pripravit' človeka na neustále sa meniaci svet, kultivovat' jeho pevnú osobnost' a podl'a J. Pelikana (2011: 26) orientovat' človeka tak, aby bol pripravený odolávat' otrasom spoločnosti.

Podstatou kultivácie l’udskej individuality je rozvíjanie osobnostných kvalít a schopností potrebných pre uplatnenie na nadnárodnej úrovni. To si vyžaduje kvality človeka múdreho a morálneho.

\section{Múdrost' ako predpoklad životného úspechu}

Adaptívnou hodnotou pre l'udstvo, podl'a evolučnej hermeneutiky, je odvaha, sloboda, cnost' a múdrost'. (Csikszentmihalyi - Rathunde, 1990 in Ruisel, 2005). Múdrost' vymedzuje I. Ruisel (2005: 115) ako poznávací proces alebo ako zvláštny spôsob získavania a spracúvania informácií, ako cnost' alebo sociálne hodnotnú formu správania sa a ako dobro alebo osobnostne žiaduci stav alebo podmienku.

R. J. Sternberg (2002: 498) definuje múdrost' „ako výnimočný vhl'ad do l'udského vývoja a životných udalostí, vrátane výnimočne dobrého posudzovania alternatív, a tiež schopnost' poradit' pri riešení životných 
problémov“. Vymedzil šest' faktorov l'udskej múdrosti: usudzovacia schopnost', bystrost' (chytrost'), učenie sa z myšlienok iných l'udí a z prostredia, posudzovanie alternatív, rýchle použitie informácií a dôvtipnost' (intenzívna schopnost' uvedomenia, vnímania a vhl'adu).

Múdrost' človeka je posudzovaná podl'a toho ako:

- spoznáva realitu rôznych formálnych systémov prostredníctvom životných skúseností a je schopný pripúšt'at aj opačné názory,

- predpokladá vzájomné súvislosti svojich skúseností a chápe dopady ich zmeny a transformácie

- prijíma skôr reflexívny a integratívny prístup $\mathrm{k}$ mysleniu

- realizuje svoje vol'by v súlade so záväzkami a s určitými činnost’ami. (Ruisel, 2005: 118).

Predpokladá sa, že rozhodovanie múdreho človeka je ovplyvnené vel'kou „š́rkou“ (empatia), „výškou“ (inteligencia) a „hĺbkou“ (reflexivita), ktoré mu umožňujú komplexnejšie, konkrétnejšie a abstraktnejšie uchopit’ určité problémy, a tým optimálne konat'. Múdry človek prostredníctvom spontánneho záujmu o svet získava bohaté skúsenosti, ktoré je schopný primerane využit' pomocou svojho intelektuálneho nadhl'adu, má schopnost' hl'adiet' na problém alebo situáciu a riešit' ich. (Ruisel, 2005: 123).

Ide podl'a P. Baltes a J. Smith (tamtiež, p. 122) o expertnost', či základnú pragmatiku života. Múdrost' prepája poznávacie procesy a afekty, čím sa zvyšuje poznávacia výberovost', motivácia a primeranost' spracovania informácií.

V poňatí racionality verzus dysracionálnosti v správaní je racionálne správanie ekvivalentom múdreho správania a dysracionálne správanie ekvivalentom hlúposti. R. J. Sternberg (2004: 269-280) sa domnieva, že l'udskú hlúpost' treba chápat' v zmysle nerozvážnosti a svoju teóriu i nazval ako „nerozvážnu teóriu nerozumnosti“. Začiatky nerozumnosti ležia v nedostatku skrytých poznatkov. Skryté poznatky sú na činnost' orientované poznatky, zvyčajne získané bez priamej pomoci druhých, ktoré umožňujú človeku dosiahnut' ciele osobného významu. Skryté poznatky majú tri hlavné črty:

- sú procesuálne,

- sú relevantné pre dosiahnutie ciel’ov, ktoré si l'udia cenia,

- sú nadobudnuté s malou pomocou druhých, resp. celkom bez nej.

Skryté poznatky znamenajú ,vediet' ako“. Ide o vhl'ad do vzt'ahu medzi podmienkami a dôsledkami konania (produktívne systémy), užitočný pre pochopenie mentálnej reprezentácie skrytých poznatkov. Skryté poznatky sú užitočné prakticky. Sú inštrumentálne smerom k dosiahnutiu ciel'ov, o ktoré l'ud'om ide. Preto l'udia používajú tieto poznatky, aby v živote dosiahli úspech, nech už ho definujú akokolvvek. Abstraktné poznanie postupu riešenia problému, ktoré nemajú vzt'ah k životu, sa $\mathrm{z}$ tohto pohl'adu nebudú chápat' ako súčast' skrytých poznatkov.

Priklad: Predstavte si, že je pondelok a vy potrebujete povedat' svojmu šéfovi zlú správu. Pritom viete, že pondelkové rána výrazne ovplyvňujú jeho náladu počas celého týždña. Dozviete sa okrem iného, že váš šéf každú nedelu hráva futbal, ale včera sa zápas nemohol uskutočnit kvôli zlému počasiu, a tak je šéf roztrpčený. V̌̌etci kolegovia radšej chodia po špičkách a obchádzajú jeho dvere. Od vás závisí, či sa budete správat rozumne a zlú správu

Slavonic Pedagogical Studies Journal, ISSN 1339-866o, Volume 5 Issue 1, February 2016 
necháte na neskôr, aby ste nezneprijemnili šéfovi, sebe a svojim kolegom celý týžden̆ alebo vbehnete do jeho kancelárie a....

Skryté poznatky sa viažu na určité situácie alebo triedy situácií.

Múdrost' a jej integrálne súčasti - skryté poznatky umožňujú mladému človeku riešit' dilemy a realizovat' životné rozhodnutia - tzv. Životné plánovanie - vychádza $\mathrm{z}$ inter a intrapersonálneho poznania a schopností. Funkcia stavia na kompetencii prekonávat' bariéry vyplývajúce zo skúseností a nezvyčajných situácií, na sebapoznávaní (poznaní vlastných pocitov, potrieb a očakávaní), schopnosti diferencovat' svoje potreby od očakávaní iných l'udí, nadväzovat' primerané medzil'udské vzt'ahy vrátane používania sociálne primeraných foriem riešenia konfliktov, otvorenosti $\mathrm{k}$ radám od iných a schopnosti prekonávania zmeny a vývinu. (Ruisel, 2005: 137).

Múdrost' sa manifestuje ako séria procesov, ktoré sú zvyčajne cyklické a vyskytujú sa v rôznom poradí. Tieto procesy súvisia s tým, čo označujeme ako „metakomponenty“ myšlienky zahŕn̆ajúce:

- Uvedomenie si existencie problému.

- Definovanie povahy problému.

- Ujasnenie informácií o probléme.

- Formulovanie stratégie riešenia problému.

- Alokovanie zdrojov určených na riešenie problému.

- Monitorovanie riešenia problému, vyhodnotenie spätnej väzby na dané riešenie.

V prípade nerozumnosti je proces riešenia problému chybný. Najčastejšie je chyba v nesprávnom definovaní problému. (Sternberg, 1985). Ak si bližšie pozrieme procesy múdrosti a nerozumnosti, vidíme, že jednotlivé procesy sú približne zhodné s fázami riešenia problému, ktoré žiakom približujeme v edukačnom procese. Ked' výsledky týchto psychologických teórii analyzujeme v kontexte pedagogiky, zákonite nám vyvstáva otázka, čo vlastne majú učitelia v škole rozvíjat'. V mnohých pedagogických dielach sa stretneme s požiadavkou rozvoja tvorivého, otvoreného, hodnotiaceho, kritického myslenia. ,Je potrebné naučit' žiakov mysliet'.“

Z podrobných analýz autorov (Baron, 1993: 199; Adams, 1993) vyplýva, že myslenie nie je doménou poznania. Ak si ako pedagógovia dávame za ciel' zlepšit' kvalitu myslenia, rozvíjat' otvorené, híbavé myslenie, v skutočnosti sa snažíme zlepšit' racionalitu myslenia.

Súčasná realita a výsledky výskumov naznačujú, že to, čo robí z jednotlivca racionálnejšieho človeka sú kompetencie $\mathrm{k}$ aktívnemu, otvorenému mysleniu. Ak má vyučovanie prispiet' k rozvoju múdrosti žiaka, musí zákonite podporovat' myslenie - otvorené, tvorivé - a neorientovat' sa výhradne na poznanie a vedomosti, ako je tomu často v našich školách. Aj bežná prax nás denne presviedča, že byt' vzdelaný alebo inteligentný ešte neznamená byt' múdry.

\section{Aspekty výchovy v konfrontácii základov personálnych kompetencií}

Ak uvažujeme o kompetenciách človeka potrebných pre uplatnenie sa a úspešnú sociálnu inklúziu, nedá nám nezamysliet' sa nad sociálnou dimenziou života človeka a jeho vzt’ahom k spoločnosti ako aj nad sebarealizáciou a vzt’ahom človeka k sebe samému. 
Zmysel života l'udskej bytosti sa vytvára v konkrétnom spoločenstve l'udí, preto je dualita vzt'ahu človek a spoločnost' edukačne mimoriadne významná. $\mathrm{Na}$ jednej strane je človek od spoločnosti závislý, no na strane druhej nie je pasívnym subjektom a $\mathrm{v}$ istých kontextoch je od spoločnosti nezávislý. Len podporovaním nezávislosti jednotlivca (žiaka) od spoločnosti v procese výchovy môže spoločnost' (učitel') podporit' procesy zmien spoločnosti.

Žiak si osvojuje sociálne pravidlá, podriad'uje sa im, sú základným predpokladom prípravy na život v spoločnosti, nevyhnutné pre úspešnú socializáciu a samozrejme sociálnu inklúziu. Zároveň spoločnost' potrebuje pre svoj vývin l’udskú reflexiu a konanie, čo si vyžaduje nezávislost' od sociálnej skupiny, systému, odstup, nadhl'ad. Podmienkou je posilňovanie schopnosti mladého človeka zaujímat' a vyjadrovat' postoje $\mathrm{k}$ spoločenskému dianiu, podporu vedomia spoločného zdiel'ania každodenného sveta, posilňovanie zodpovednosti, aktívnu angažovanost' pre spoločné a individuálne dobro a nel'ahostajnost'.

Výchova má viest' $\mathrm{k}$ rozvoju slobodných nezávislých autentických osobností, ktoré sú schopné aj vzdorovat' sociálnemu nátlaku, angažovane a pritom zodpovedne spoločnost' a sociálne vzt'ahy tvorit', rekonštruovat' a inovovat'. (Kosova, 2013: 46).

Je dôležité edukačne správne podporovat' procesy stávania sa „samých sebou".

Byt' sám sebou predstavuje osobnostnú dimenziu života človeka a úzko súvisí so sebarealizáciou. Ide o vlastný životný program, ktorým je človek jedinečný, odlišný, iný. Byt' sám sebou zároveň znamená potvrdzovat' svoju existenciu činmi, zanechat' niečo $\mathrm{v}$ živote niekoho iného, stopu v myšlienkach druhého, realizovat' vlastné schopnosti a možnosti, stat' sa tým, čím sa môže stat'. Sebarealizácia teda nie je len uspokojením vlastných potrieb. (tamtiež p. 47).

U mladého človeka sa neraz stretávame s problémom orientácie vo vlastnom sebapoňatí, vlastnej identite a hodnotovej orientácii a významnú úlohu aj v štádiu adolescencie zohráva učitel'. Učitel’ovo pôsobenie na hodnotovú sféru osobnosti žiaka považuje G. Pintes (2012: 83) za fundamentálny prvok, nenahraditel'ný iným aspektom, ked’že existencia, resp. absencia tohto hladiska (v učitel'ovej koncepcii) môže byt' dôvodom $\mathrm{k}$ tomu, aby sme o nejakom procese mohli skutočne tvrdit', že vôbec ide (alebo nie) o výchovný proces, $\mathrm{v}$ ktorom by malo dôjst' $\mathrm{k}$ pozitívnym zmenám $\mathrm{v}$ osobnosti vychovávaného.

Proces, $\mathrm{v}$ ktorom sa nesmeruje $\mathrm{k}$ interiorizácii hodnôt nie je možné považovat' za výchovný. Ide o to, či sa učitel' chce spolupodiel'at' na procese interiorizácie hodnôt, alebo túto rolu prenechám niekomu inému. Je to rozhodujúca dilema, od ktorej $\mathrm{v}$ zásadnej miere závisí aj učitelova pozícia. Ak totiž rezignuje na túto funkciu, stáva sa len akýmsi dozorcom spontánneho formovania osobnosti vychovávaného.

Inšpiráciou pre vlastnú individuálnu pedagogickú koncepciu učitel’a predstavujú publikácie teoretikov výchovy opierajúce sa práve o analýzu

Slavonic Pedagogical Studies Journal, ISSN 1339-866o, Volume 5 Issue 1, February 2016 
duality vzt’ahu jednotlivca a spoločnosti. Z viacerých orientujeme pozornost' čitatel'a na práce J. Pelikana (2011) a Z. Matejceka (2004).

J. Pelikan (2011) charakterizoval „klúčovú sedmičku“ otvorenú hl'adaniu nových integrovaných kvalít osobnosti, smerujúcich k novému poňatiu výchovy. Ide o výchovu orientovanú na:

1. hl'adanie a nachádzanie zmyslu existencie,

2. adekvátnu reflexiu - aby človek pochopil svoje možnosti a dokázal sa stat' subjektom vlastného konania,

3. zaujatie aktívnej životnej pozície - vychádzajúcej zo spoločného zdiel'ania sveta (autor píše o hlavnom prediktore uplatnenia sa v živote),

4. výchovu charakteru a zameranie osobnosti - jej podstata je utváranie osobného svetonázoru, vnútorne prijaté hodnotové preferencie tvorba osobnej životnej pozície,

5. pozitívnu emocionalita - založená na schopnosti pozitívne vnímat' svet a jednotlivé situácie, čo pomáha človeku riešit' zložité životné problémy.

6. rozvíjanie zmyslu pre zodpovednost' prostredníctvom poskytnutia slobody rozhodovania

7. citovost' a citlivost' k ostatným l'ud'om - spočívajúcu vo výchove $\mathrm{k}$ orientácii vo vlastných citoch, výchove k zvládaniu emócií, výchove k schopnosti sám seba motivovat', výchove k vnímaniu emócií druhých, k pomoci a súcitu a prosociálnosti.

Uvedené orientácie chápeme ako bázu, výchovný fundament pre úvahy o rozvíjaní kompetencií pre uplatnenie sa, či už v systémoch formálneho alebo neformálneho vzdelávania.

\section{Filozofia sprostredkovania v edukačnom procese ako predpoklad úspešnej sociálnej inklúzie}

Sprostredkovanie vo vyučovaní je chápané ako kognitívne vedenie, ktoré sa primárne zameriava na zmeny v štruktúre kognitívnych funkcií. Pretože (v nadväznosti na predchádzajúci text), umožňuje získat' skryté poznatky, ktoré sú viac ako len vedomosti a zručnosti. Základom efektívneho sprostredkovania je kanál (vzt'ah) medzi učiacim sa subjektom a učitel'om (sprostredkovatel'om). J. Lebeer (1994), R. Feuerstein, S. Klein, A. Tannenbaum (1991), A. Kozulin (1994), zdôrazňujú, že sprostredkovanie je vprocese učenia efektívnejšie, pretože nenecháva učiaceho sa v obmedzenom svete tým, že rozvíja vyššiu formu kognitívnych zručností, ktoré sú dôležité pre adaptáciu v nových situáciách ako samostatné učenie. Podstatou sprostredkovaného učenia je uvedomenie si, že to čo sa učím teraz, využijem v konkrétnej situácii. Nie každé vyučovanie je sprostredkovaním. Môžeme dokonca povedat, že máloktoré je sprostredkujúce. Ak učitel’ iba dáva žiakom inštrukcie, úlohy a informácie a hovorí ako a čo majú robit', ponúka iba historické alebo vedecké fakty, nejde o sprostredkovanie, pretože neumožňuje získat' sprostredkujúcu skúsenost', ktorá je nositel'om štrukturálnej zmeny. Nedochádza k rozvoju kognitívnych funkcií ani autonómneho učenia. 
Význam kognitívnej modifikácie spočíva $\mathrm{v}$ tom, že umožníme žiakovi adaptovat' sa pre podmienky života l'udstva.

Žijeme v podmienkach, kde neadaptovaní jednotlivci sú stratení v mnohých smeroch svojho bytia, sú odsúdení na život, ktorý bude neprestajne obmedzovaný. Tento fakt by mal byt' výzvou pre každého pedagóga, aby úroveň jeho psychodidaktických, ontodidaktických a realizačných kompetencií bola taká vysoká, že zvládne a bude efektívne realizovat' kognitívnu modifikáciu každého diet’at'a jemu zvereného (Duchovicova, 2010: 53).

Kognitívne funkcie ktoré majú byt' sprostredkovaním rozvíjané vymedzujú R. Feuerstein, Y. Rand, M. Hoffman a R. Miller (1980) ako základ myslenia. Predstavujú súbor nástrojov umožňujúcich porozumiet’ zložitosti sveta a nachádzat' riešenia problémov a úloh. Kognitívne funkcie rozdelili na tri skupiny:

- oblast' prijímania podnetov a získavania informácií (input),

- oblast' spracovania informácií a riešenie problémov

- oblast' formulovania riešení (output).

Tabul'ka 1 Kognitívne funkcie

\begin{tabular}{|c|c|c|}
\hline \multicolumn{3}{|c|}{ Kognitívne funkcie } \\
\hline $\begin{array}{l}\text { Prijímanie podnetov } \\
\text { získavanie informácii }\end{array}$ & Spracovanie informácii & $\begin{array}{l}\text { Riešenie problémov- } \\
\text { formulovanie riešení }\end{array}$ \\
\hline $\begin{array}{c}\text { Zretel'né a sústredené } \\
\text { vnímanie }\end{array}$ & $\begin{array}{l}\text { Rozpoznávanie a určenie } \\
\text { problému }\end{array}$ & $\begin{array}{c}\text { Zrozumitel'né } \\
\text { sebavyjadrenie }\end{array}$ \\
\hline $\begin{array}{l}\text { Systematické vyhl'adávanie } \\
\text { informácií }\end{array}$ & Výber dôležitých informácií & $\begin{array}{l}\text { Vytváranie predstáv } \\
\text { o realistických súvislostiach }\end{array}$ \\
\hline $\begin{array}{c}\text { Označovanie, } \\
\text { pomenovávanie }\end{array}$ & Spontánne porovnávanie & $\begin{array}{c}\text { Predchádzanie psychickému } \\
\text { bloku }\end{array}$ \\
\hline $\begin{array}{l}\text { Popis pozície a miesta } \\
\text { (orientácia v priestore) }\end{array}$ & $\begin{array}{l}\text { Rozširovanie mentálneho } \\
\text { obzoru }\end{array}$ & $\begin{array}{c}\text { Snaha vyhnút' sa postupu } \\
\text { pokus-omyl }\end{array}$ \\
\hline $\begin{array}{l}\text { Popis časopriestoru } \\
\text { (orientácia v čase) }\end{array}$ & $\begin{array}{c}\text { Spájanie a vytváranie } \\
\text { súvislostí }\end{array}$ & Používanie správnych slov \\
\hline Zachovanie stálosti & $\begin{array}{c}\text { Tendencia hl'adat' logické } \\
\text { zdôvodnenia }\end{array}$ & Potreba presnosti \\
\hline Presnost' & Internelizácia (zvnútornenie) & $\begin{array}{c}\text { Zrakové spracovanie } \\
\text { informácie } \\
\end{array}$ \\
\hline $\begin{array}{c}\text { Kombinovanie dvoch } \\
\text { a viacerých zdrojov } \\
\text { informácií }\end{array}$ & $\begin{array}{l}\text { Formulovania hypotéz, } \\
\text { deduktívne myslenie }\end{array}$ & Obmedzenie impulzivity \\
\hline & $\begin{array}{c}\text { Stratégie pre overovanie } \\
\text { hypotéz }\end{array}$ & \\
\hline & $\begin{array}{c}\text { Vol'ba referenčného rámca } \\
\text { (styčné východiská pre } \\
\text { riešenie) }\end{array}$ & \\
\hline & Plánovanie & \\
\hline & Slovné pomenovávanie & \\
\hline
\end{tabular}

Zdroj: Feuerstein, R. - Rand,Y. - Hoffman, M. - Miller, R. (1980)

Kognitívna modifikácia dosahovaná sprostredkovaním je postavená na nasledovných kognitívnych kl'účoch.

Slavonic Pedagogical Studies Journal, ISSN 1339-8660, Volume 5 Issue 1, February 2016 
1. Porozumenie problému a kladenie otázok. $\mathrm{Z}$ didaktického hl'adiska ide o prezentáciu možného situačného problému. Zahŕňa vytváranie pozitívneho postoja $\mathrm{k}$ riešenému problému, zvyšovanie vedomej potreby organizovat' a plánovat' informácie, učenie sa jednoduchým stratégiám riešenia problému, usporadúvania, porozumenia otázkam a ich vzt’ahu k odpovediam, porozumenie ako je myslenie dôležité.

2. Porozumenie potrebe pracovat presne a výstižne. Prezentácia situačného problému môže byt' založená na problémoch, ktoré vzniknú pri nepresnom používaní reči (vyjadrovaní) ako hlavného nástroja problému. Ciel’om môže byt' porozumenie roly reči $\mathrm{v}$ komunikácii, zvýšenie motivácie porozumiet' verbálnym výrazom, naučit' sa klást' otázky, požiadat' o vysvetlenie, zvýšenie potreby naučit' sa nové slová.

3. Orientácia v čase a priestore. Ciel'om je rozvoj schopnosti hodnotit' časový rámec a organizovat' čas.

4. Štruktúrovanie informácií. Ciel'om je porozumiet' vzt'ahu medzi úlohou a informáciou, rozpoznat' zdroje informácií, naučit žakov pracovat' presne, precízne a systematicky, naučit' ich skúmaniu častí, ktoré tvoria celok, odstránenie riešení pokusom a omylom, rozvoj slovných nástrojov.

5. Nácvik pracovnej pamäti. Ciel'om je uvedomit' si kapacitu vlastnej pamäti a to, aký význam má pamät' pri riešení problémov, učit' sa používat' nápovedy, klúče pre rozvoj pracovnej pamäti.

6. Selektívna orientácia pozornosti. Ciel'om je zvyšovanie vedomia potreby zamerat' pozornost' na situačný problém, no môžeme vyvodit' aj vzt'ahy medzi aktivitou a odmenou a poukázat' na význam sebaregulácie pre splnenie ciel'ov.

7. Vyhl'adávanie vztahov. Ciel'om je porozumenie vzt'ahu medzi príčinou a následkom, uvedomenie si potreby rozumiet' základným prvkom.

8. Odhalovanie podstatného. Ciel'om je opätovné zdôraznenie prvkov a ich dôležitosti pri riešení problému, uvedomenie si potreby rozumiet' podstate veci.

9. Rozvoj plánovacích kompetencií. Ciel’om je zvýšit' uvedomenie si významu účelného plánovania pri riešení problému, učit sa jasne si formulovat' ciel', uvedomit' si, že plánovanie musí zahrnút' aj správanie sa a čas.

10. Vedomie kompetencie. Posledný uvádzaný klúč považujeme za najpodstatnejší pre stimuláciu vnútornej motivácie. Učí reflektovat' svoje myslenie, vhl'ad do problémov a hodnotit' svoje poznávacie zručnosti, čím sa rozvíja metakognícia alebo metamyslenie (bližšie Duchovicova Zovinec, 2009).

Mediované (sprostredkované) učenie, ako ho označuje Z. Petrova (2009) sa snaží zabezpečit', aby učebné aktivity nerozširovali len rozsah poznania žiaka, ale taktiež napomáhali budovaniu kvalitatívne vyšších foriem fungovania psychických funkcií žiaka - od náhodných, na kontexte závislých a autonómne neregulovatel'ných postupov riešenia úloh smerom $\mathrm{k}$ vedomej, zámernej a na percepčno-činnostnom kontexte nezávislej mentálnej činnosti.

Takéto učenie umožňuje vytváranie kognitívnych funkcií, predpokladov pre neskoršie nezávislé a my dodávame celoživotné učenie, ako to dokazujú 
výsledky experimentov R. Feuersteina, S. Kleina, A. Tannenbauma (1991), A. Kozulina (1994), J. Lebeera (1994) a sú tak predpokladom úspešnej sociálnej inklúzie.

\section{Personálne kompetencie pre uplatnenie na trhu práce}

Globalizačné procesy postupne ovplyvňujú aj systémové riešenia $v$ rámci edukácie a hodnotenie jej efektov. Konkretizáciu ciel’ov edukácie predstavujú vymedzenia klúčových vedomostí, zručností a kompetencií nevyhnutných pre úspešné sociálne začlenenie a uplatnenie na trhu práce. Ciel'om je zabezpečit' porovnatel'nost', transparentnost', prenosnost' a uznávanie kvalifikácií. Podobne ako systém ECTS vo vysokoškolskom vzdelávaní, bol vytvorený systém prenosu kreditov pre odborné vzdelávanie a prípravu ECVET, ktorý podporuje spoločný rámec referenčnej úrovne pre kompetencie a vzdelávanie (bližšie Winterton Delamare - Le Deist - Stringfellow, 2005).

Snahy vychádzajú predovšetkým z hodnotenia krízy spoločnosti a očakáva sa, že dôraz kladený na vedomosti, zručnosti a kompetencie ako edukačné efekty, resp. výsledky vzdelávania zabezpečia udržatel'ný rozvoj v spoločnosti. Postupne sa prostredníctvom rôznych foriem neformálneho vzdelávania vytvára priestor pre jednotlivcov, ktorí sú limitovaní absolvovat' vyššie stupne formálneho vzdelávania s ciel'om rozšírit' možnosti uplatnenia na trhu práce.

Pojem kompetencia preniká do politiky vzdelávania a zároveň sa stáva prvkom premost'ujúcim ciel'ové vedomosti a zručnosti s adresnými požiadavkami pre výkon povolania. Predstavuje tak nutný predpoklad, očakávanie vzt’ahujúce sa na konkrétnu profesiu. Ako s relatívne novým pojmom $\mathrm{v}$ rámci edukačných vied je $\mathrm{v}$ jeho presnom vymedzení skôr definičný chaos. Synteticky v ňom nachádzame základné konceptové pozície:

1. chápanie kompetencie ako právomoci v socio-kultúrej praxi,

2. psychosociálne charakteristiky osobnosti, atribúty ovplyvňujúce uplatnenie vedomostí a zručností, mikro úroveň pracovného výkonu,

3. odborné štandardy, teda to čo l'udia musia byt' schopní urobit' pri výkone činnosti viažuce sa ku konkrétnej profesii.

Psychologický pohl'ad taktiež nie je jednotný. V prácach R. Gelmana a J. G. Greenoa (1989) a S. Sophiana (1997) sa stretávame s vymedzením:

- koncepčných kompetencií - predstavujú pravidlá, abstraktné vedomosti o celej oblasti;

- procedurálnyh kompetencií - postupy a zručnosti potrebné k uplatneniu koncepčných kompetencií v konkrétnych situáciách

- funkčných kompetencií - uplatňujú sa pri posudzovaní problémov a výbere optimálnych stratégií pre ich riešenie.

Zdôrazňovaný kognitívny aspekt $\mathrm{v}$ prístupoch psychológov sa stretol s kritikou a vymedzenie kompetencií sa rozšírilo o rozmer učenia a praxe, čím dostali kompetencie objektívny (výkon a potenciálny výkon porovnatel'ný so štandardami) a subjektívny (schopnosti a zručnosti potrebné pre zvládanie úloh súvisiacich s výkonom) rámec. 
T. Staudel (In Winterton - Delamare - Le Deist - Stringfellow, 2005: 15) rozdel'uje subjektívne kompetencie na skupiny :

- heuristické kompetencie - predstavujú všeobecný systém účinného uplatnenia schopností $\mathrm{v}$ rôznych situáciách - generalizované sebaponímanie,

- epistemologické kompetencie - poznanie vlastných špecifických zručností a vedomostí - špecifické sebaponímanie,

- aktuálne kompetencie - momentálne subjektívne sebavedomie, predstava o vlastnej výkonnosti vyplývajúca zo vzdelaním nadobudnutých vedomostí, zručností a schopností,

- akčné kompetencie - všetky kognitívne, motivačné a sociálne predpoklady

úspešné učenie a sebarealizáciu. K týmto kompetenciám autor zarad'uje:

- kompetencie pre všeobecné riešenie problémov,

- kritické myslenie,

- doménu všeobecných a špecifických poznatkov,

- realistické, pozitívne sebavedomie,

- sociálna kompetencie,

- osobnú hodnotovú orientáciu,

- $\quad$ špecifické a nešpecifické odborné kompetencie.

T. D. Nelson a L. Narens (1990) zaviedli pojem metakompetencie, ktoré predstavujú poznanie vlastných silných a slabých stránok uplatnenia vedomostí a zručností v rôznych pracovných situáciách a poznanie stratégií získania chýbajúcich kompetencií. Predstavujú kognitívne aspekty práce najmä v procesoch učenia.

Personálne kompetencie podl'a Nelsonsgrup (2003) predstavujú tzv. mäkké zručnosti a podl'a nášho názoru majú bezprostredný vplyv na uplatnenie sa na trhu práce, efektívny výkon spojený s povolaním ako aj na úspešnost' $\mathrm{v}$ procesoch formálneho, či neformálneho vzdelávania a celoživotného učenia.

Zástupcovia Nelsonsgrup rozdel'ujú personálne kompetencie do troch kategórií. Analyzujú kompetencie osobné, behaviorálne a tzv. osobnostné motivátory. Z inventáru osobných kompetencií vyberáme:

- Zodpovednost' $k$ ostatným - zodpovednost' za následky správania a výsledky svojich rozhodnutí.

- Počúvanie - otvorenost' a ochota počúvat' l'udí a počut' čo hovoria (nie to čo si myslíme, že hovoria alebo by podl'a očakávaní mali hovorit').

- Zmysel pre detail - schopnost' vidiet' a venovat' pozornost' detailom, schopnost' rozpoznat' konštrukčné prvky riadenia alebo objektov a overovat' správnost' alebo chybnost' častí celkov alebo postupov.

- Ponímanie poctivosti - osobný pohl'ad na a poctivost', štruktúru spoločenského poriadku, úroveň sebaúcty v kontexte prijatia dôsledkov za svoje činy a intolerancia k nepoctivosti druhých.

- Prístup kostatným - udržiavanie pozitívneho otvoreného a objektívneho postoja k ostatným.

- Vyvážené rozhodovanie - kompetencia objektívneho spravodlivého hodnotenia rôznych aspektov situácie, smerujúceho k etickým 
rozhodnutiam berúcim do úvahy komplexnost' situácií so zabezpečením rovnováhy medzi potrebami seba samého, ostatných a spoločnosti súčasne.

- Vztah k práci - vnútorná motivácia k pracovnej aktivite a schopnost' zostat' sústredený.

- Koncepčné myslenie - plánovanie dlhodobých zámerov včítane schopnosti identifikovat' a zhodnotit' zdroje.

- Organizačné kompetencie - schopnost' identifikovat' okamžité potreby a situácie a zavádzat’ akčné plány pre zabezpečenie týchto potrieb.

- Konzistencia a spravodlivost' - vnútorná motivácia pre svedomité zvládanie aktivít vyplývajúcich zo životných rolí.

- Kompetencie pre kontrolu - schopnost' čelit' kontroverzným alebo t'ažkým otázkam objektívnym spôsobom, ovládat' emócie a riešit' problémy disciplíny bez emocionálnej zainteresovanosti.

- Kreativita - schopnost' prispôsobit' tradičné metódy, koncepty, modely, vzory, technológie alebo systémy do nových aplikácií, alebo schopnost' navrhnút' nové prístupy $\mathrm{k}$ ich zlepšeniu alebo riešeniu problémov.

- Kontrola emócií, sebakontrola - schopnost' vystupovat' racionálne a objektívne v stresových alebo emocionálne vypätých situáciách, udržanie pokoja $\mathrm{v}$ t’ažkých situáciách bez impulzivity konania.

- Empatia - schopnost' vnímat' a pochopit' pocity a postoje druhých;

- Hodnotenie v kontexte ostatných - schopnost' robit' realistické a presné úsudky o druhých, zhodnotit' svoje silné a slabé stránky, pochopit' spôsob myslenia iných, otvorenost' $\mathrm{k}$ l'ud'om a ochota počut' to, čo hovoria ostatní.

- Flexibilita - schopnost' rýchlo menit' zameranie myslenia a integrovat' zmeny s minimálnym osobným odporom.

- Zvládanie odmietnutia - schopnost' zvládnut' odmietnutie na osobnej úrovni, schopnost' vidiet' samého seba ako cennej bytosti nezávisle od svojej roly alebo pozície $\mathrm{v}$ živote.

- Zvládanie stresu -schopnost' vyvážit' a zmiernit' vnútorné napätie, schopnost' vhodne sa oddelit' od stresových situácií a udržiavat' svoj vlastný zmysel pre vnútorný mier.

- Etika práce - osobný záväzok pre vykonávanie určitej úlohy.

- Dodržiavanie noriem - schopnost' vidiet' a pochopit' podstatnost' stanovených požiadaviek pri práci

- C Cítanie l'udí - schopnost' "čítat' medzi riadkami" prostredníctvom reči tela, zdržanlivosti, stresu a emócií druhých.

- Osobná zodpovednost' - schopnost' byt' zodpovedný za následky vlastných rozhodnutí a opatrení a nepresúvat' vinu alebo príčiny zlých výkonov inde.

- Proaktivna myslenie - schopnost' zhodnotit' budúce dôsledky súčasných rozhodnutí a činnosti, schopnost' mentálne vytvorit' scenáre a výsledky situácií, ktoré by sa mohli vyvinút' na základe rozhodnutia. 
- Orientácia na výsledky - schopnost' identifikovat' kroky potrebné na dosiahnutie úlohy, získanie výsledkov, schopnost' plnit’ plány, termíny, kvóty a výkonnostné ciele a pod.

- Sebazdokonalovanie - motivácia, orientovaná na seba zlepšovanie, motivácia $\mathrm{k}$ získaniu vzdelania a vzdelávacích príležitostí $\mathrm{k}$ d’alšiemu rastu.

- Self management - schopnost' stanovovat' si priority a plnit' úlohy s ciel'om dosiahnutia požadovaných výsledkov.

- Použivanie zdravého rozumu - schopnost' sústredit' sa na praktické myslenie, schopnost' vidiet' svet jasne.

\section{Záver}

Inventáre kompetencií sú vytvárané $\mathrm{v}$ rámcoch jednotlivých profesií a vo svojich tvrdých ukazovatel'och (vedomosti, zručnosti, spôsobilosti) sú základom profilov vzdelávacích programov, no nemenej dôležité sú mäkké kompetencie. Spoločnost' a zamestnávatelia vplyvom globalizačných zmien azda viac ako kedykol'vek predtým stavajú profesijný profil na múdrosti, ktorá vychádza zo skrytých procesuálnych poznatkov a vedomosti (na ktorých stoja vzdelávacie programy) ustupujú do úzadia. Skryté poznatky, teda schopnost' vhl'adu absolventa do vzt'ahu medzi podmienkami a dôsledkami konania predstavuje potenciálny produktívny systém, preto je oceňovaný viac ako abstraktné poznanie postupu riešenia problému, ktorý nemá vzt’ah k životu a $\mathrm{k}$ praxi. Dôraz kladený na personálne kompetencie si žiada $\mathrm{v}$ príprave absolventov sekundárnych a terciárnych stupňov formálneho vzdelávania, ako aj $\mathrm{v}$ neformálnom vzdelávaní návrat $\mathrm{k}$ humánne hodnotným ideám výchovy, na ktoré sme v každodennom prúde edukačnej činnosti tak trochu zabudli a prechod od transmisie hotových poznatkov $\mathrm{k}$ sprostredkovaniu, vedenie $\mathrm{ku}$ konštruovaniu významov a rozvíjaniu kritického myslenia a schopnosti argumentácie.

\section{Bibliographic references}

ADAMS, M. J. 1993. Towards making it happen. In Applied Psychology: An International Review, n. 42, pp. 214-218.

BARON, J. 1993. Why Teach thinking? - An essay. In Applied Psychology: An International Review, n. 42, pp. 191-214.

BECK, U. 2007. Co je to globalizace? Omyly a odpovědi. Brno: Centrum pro studium demokracie a kultury. 197 s., ISBN 9788073251239.

BIROVA, J. - ELIASOVA, S. 2014. Viacjazycná a plurikulturna kompetencia a vyucovanie cudzich jazykov na zakladnych a strednych skolach v Slovenskej republike. In XLinguae Journal, vol.7, n. 1, pp. 75-82. ISSN 13398660.

DUCHOVICOVA, J. 2010. Neurodidakticky a psychodidakticky kontext edukacie. Nitra: PFUKF. ISBN 9788080947835.

DUCHOVICOVA, J. - ZOVINEC, E. 2011. Rozvoj kognitivnych funkcii a sprostredkovane ucenie $\mathrm{v}$ edukačnom procese $\mathrm{u}$ deti $\mathrm{v}$ MS a na 1 . stupni ZS. In Szesciolatek : przedskolak czy uczen ? : dylematy w ksztalceniu i 
wychowaniu dzieci najmlodszych. Gliwice: GWSP, pp. 129-146, ISBN 9788361401681.

FEUERSTEIN, R. - RAND, Y. - HOFFMAN, M. B. - MILLER, R. 1980. Instrumental enrichment: An intervention program for cognitive modifiability. Baltimore, MD: UPP, ISBN 0673246000.

FEUERSTEIN, R. - KLEIN, S. - TANNENBAUM, A. 1991, 1994. Mediated Learning Experience (MLE). Theoretical, psychological and learning implications. London: Freund Publishing House. ISBN 9652940852.

GELMAN, R. - GREENO, J. G. 1989. On the nature of competence. Principles for understanding in a domain. In L. B. Resnick (ed.) Knowing, Learning and Instruction, Hillsdale, NJ : Erlbaum, pp. 125-186.

KOSOVA, B. 2013. Filozoficke a a globalne suvislosti edukacie. Banska Bystrica : UMB, 173 s. ISBN 9788055704340.

KOZULIN, A.1994. Mediation and the acculturation process. In Garbo, R. - Lebeer, J. (ed): Search of learning potential. Proceedings of the first European Conference on Instrumental Enrichment and Mediated Learning. Antwerpen/Den Haag: EAMC\&Sardes, pp. 164-165.

LEBEER, J. 1994. You are more than your brain. Plasticity of Children with Neurological Impairments in the context of family Interaction. Antwerpen/Utrecht: Doctoral thesis.

LORENZ, K. 1990. 8 smrtelných hříchú. Praha: Pyramida. ISBN 8070382120.

NELSON, T. O. - NARENS, L. 1990. Metamemory: A theoretical framework and some new findings, In Bower, G. H. (ed.): The psychology of learning and motivation. New York : Academic Press, 1990, pp. 125-173. Available online: http://aris.ss.uci.edu/ Inarens/1990/Nelson\&Narens Book_Chapter_1990.pdf

MATEJCEK, Z. 2004. Psychologicke eseje (z konce kariery). Prague: Karolinum. ISBN 8024608928.

MEZRICKY, V. 2003. Peripetie procesu globalizace. In Mezricky, V. (ed): Globalizace. Praha: Portal, pp. 93-114, ISBN 8071787485.

PINTES, G. 2012. Vychova ako pedagogicky proces $\mathrm{z}$ aspektu teorie vychovy a vychovávania. In Duchovicova, J. - Kurincova, J. a kol. Teoreticke zaklady vychovy a vzdelavania. Nitra: PF UKF. pp. 64-101. ISBN9788055801445.

PELIKAN, J. 2011. Hledani teziste vychovy. Prague: Karolinum. ISBN 0788024612652.

PETROVA, Z. 2009. Mediovane ucenie: teoreticke suvislosti a moznosti jeho aplikácie do predprimarneho vzdelavania. In Acta Facultatic Pedagogicae Universitatis Tyrnaviensys. Trnava: PF TU, n.. 13, pp. 96-107. ISBN 978-80-8082-324-5.

PETRUSEK, M. 2003. Socialni souvislosti globalizace : globalizace jako postmoderni ambivalence. In Mezricky, V. ed: Globalizace. Prague: Portal, pp. 93-114, ISBN 8071787485.

PIKE, G. - SELBY, D. 1994. Globalni vychova. Prague: Grada. ISBN 8085623986.

Slavonic Pedagogical Studies Journal, ISSN 1339-8660, Volume 5 Issue 1, February 2016 
RUISEL, I. 2005. Mudrost v zrkadle vekov. Bratislava: IKAR. ISBN 805511059X.

SOPHIAN, S. 1997. Beyond competence: The significance of performance for conceptual development. In Cognitive Development, n.12, p.281-303.

STERNBERG, R. J. 1985. Beyond IQ: A triarchic theory of human intelligence. Cambridge : University of Cambridge.

STERNBERG, R. J. 2002. Kognitivna psychologia. Prague : Portal. ISBN 8071783765 .

STERNBERG, R. J. 2004. Mudri nie sú hlupi, ale mozu byt' nerozumni. Nerovnovazna teoria nerozumnosti. In Sternberg, R. J.: Preco robia mudri ludia hluposti? Bratislava : IKAR, s. 269-280, ISBN 805510767X.

THE NELSONSGRUP. 2003. List of Soft Skill Competencies with Descriptions. [cit. 03-10-2013]. Available online: http://www.nielsongroup. com/articles/list_of_competencies.pdf

WINTERTON, J., DELAMARE - LE DEIST, F., STRINGFELLOW, E. 2006. Typology of knowledge, skills and competences: clarification, of the concept and the prototype. Luxembourg: Office for Official Publications of the European Communities, ISBN 9289604271. Available online: https://infoeuropa.eurocid.pt/files/database/000037001-

000038000/000037620.pdf

doc. PaedDr. Jana Duchovičová, PhD.

prof. PhDr. Gabriela Petrová, CSc.

Department of Education

Faculty of Education

Constantine the Philosopher University

Dražovská cesta 4, 94974 Nitra

Slovakia

jduchovicova@ukf.sk

gpetrova@ukf.sk 